\title{
Madrasah Management Post Transfer From Private to State (Case Study at Madrasah Ibtidaiyah Negeri (MIN) Dua in Serang Regency, Banten)
}

\author{
Iyoh Mastiyah ${ }^{1}$, Farida Hanun ${ }^{2}$, Sumarni ${ }^{3}$, Opik Abdurrahman Taufik ${ }^{4}$ Hayadin $^{5}$, \\ Muhamad Murtadho ${ }^{6}$, Basuki As'ad ${ }^{7}$ \\ \{mastiyah9@gmail.com ${ }^{1}$, farida ridwan@yahoo.com², marni-chi@gamil.com ${ }^{3}$, \\ taufikrachman74@gmail.com ${ }^{4}$, hayadin006@gmail.com ${ }^{5}$, thadho25@gmail.com ${ }^{6}$, \\ basuki_afi@yahoo.com ${ }^{7}$ \} \\ Puslitbang Pendidikan Agama dan Keagamaan Balitbang Kementerian Agama 1,2,3,4,5,6 \\ Institut Agama Islam Negeri (IAIN) Ponorogo Jawa Timur ${ }^{7}$
}

\begin{abstract}
This paper is the result of research that explores the management of madrasahs after the transition from private to public at MIN Dua in Serang Regency. The method used in this research is qualitative with data collection techniques, observation, interviews, and document study. The research findings indicate that madrasah management in its implementation is very contributive to changes in performance and the achievement of the set output targets. Madrasahs strictly apply management principles both in madrasah managerial activities and madrasah operational activities. Madrasah managerial is reflected in the planning of madrasah programs carried out carefully through meetings both incidentally and periodically involving internal and external elements of the madrasah. Program implementation is distributed to employees fairly and proportionally, individually, or in teams. Likewise, program implementation is managed systematically and responsibly. All implementation of activities is directly guided and controlled in the form of supervision, monitoring, and evaluation by internal leaders and supervision by external madrasahs. All of these activities are well organized and documented, both managerial and operational activities of the madrasah.
\end{abstract}

Keywords: Madrasah, Management, Private, State

\section{Introduction}

\subsection{Research Background}

The number of madrasah in Indonesia currently reaches 82,418 madrasah, only 4,010 madrasah are managed by the government. This shows that only $4.86 \%$ is managed by the government, the remaining $95.14 \%$ is owned by private or public. Specifically for Madrasah Ibtidayah totaling 22,874, consisting of 1,686 State Madrasah Ibtidaiyah (MIN) and 24,560 Private Madrasah Ibtidaiyah (MIS). One of the madrasah that are managed by the community is Madrasah Nurul Falah, which is located in Baros, which is part of the Serang Regency area. The madrasah was founded in 1950 and is managed by the Nurul Huda Islamic Boarding School which was founded by KH. Moch Hilmi, a major scholar in the field of Falak Science 
in the Banten region. At the beginning of its establishment, the madrasah ran smoothly and progressed rapidly with up to 300 students, but now the madrasah is no longer operating because the demand for it has decreased even in 2003 it disbanded because there were no more students enrolling. Because madrasah Fakum is no longer able to manage it. Finally, the madrasah was donated by his heirs to the government after K.H.Moch.Hilmi died. While the Nurul Huda Islamic boarding school is still running, managed by his son and son-in-law (Sopuan, 2020)

Since 2003, Madrasah Nurul Huda has been managed by the government and changed to MIN 2 Serang. Since being managed by the government, it seems that the madrasah has experienced significant development, crossing other madrasah in Serang Regency. According to Muhtadi (Kasi), these two state madrasah are considered the most successful and superior in Serang Regency. Even though the employees are more dominant with honorary status, both teachers and education personnel, compared to another public madrasah in Serang Regency. The excellence and competitiveness of MIN Dua is reflected in the interest of the community in sending their children to MIN Dua, which continues to increase every year, even though there are public madrasah and elementary schools adjacent to the MIN Dua location. However, the community prefers MIN 2. For this reason, it is necessary to conduct research on how MIN Dua can excel and have the highest competitiveness for madrasah and other public schools. It is important to adopt and serve as a model that can be socialized and transmitted the values of success and excellence to another madrasah so that other madrasah become superior and successful equally.

\subsection{Research Problems and Objectives}

MIN Dua in Serang Regency is a transitional madrasah from private to state. Since being handed over to the district government, the madrasah has experienced significant development, even though its human resources and infrastructure are still limited, but due to effective management, the madrasah has experienced significant development. In particular, there are more madrasah enthusiasts every year and even many madrasah enthusiasts are rejected because the capacity of the madrasah is limited. This means that these madrasah have advantages in management and competitiveness with other public madrasah and elementary schools. Therefore it is necessary to benchmark so that it becomes a rule-model which can then be adopted, and socialized, and transmitted to another madrasah so that all madrasah are successful and excel in managing madrasah. The data from this study are useful for consideration in making policies for the Ministry of Religion in order to improve the quality of madrasah management.

\subsection{Research methodology}

This research uses qualitative methods with a case study approach and data collection techniques through observation, interviews and document study. Through the collaborative method, researchers can see firsthand the conditions of the phenomenon being studied so that it allows researchers to study various interesting new fields (Morissan, 2012: 22).To obtain accurate data, triangulation was carried out. Information or data obtained through interviews, confirmed with the results of observations and so on, also used triangulation of sources, certain information or data obtained, asked again from different informants, and compared with documentation. In addition, situation triangulation is used, in which researchers pay attention to how conditions in the field and the informants' narrative if alone, are compared 
with other people (Hamidi, 2004: 83). Furthermore, data analysis is carried out, namely, efforts made by working with data, organizing it, looking for and finding patterns, finding important things, and what is learned and deciding what to tell others (Moleong, 2005: 248). Thus, data analysis here is the stage, digging and recording data, collecting data, sorting and categorizing data, and reducing which data is inappropriate based on the scope of the study, then interpreted and narrated descriptively.

\section{Conceptual Studies}

\subsection{Management}

Etymologically, management comes from the English word "manage" which means to drive, manage and rule. In Italian, management is termed "managiere" which means to train horses. (Jawahir, 1983: 9). According to Fathurrohman, management is defined as a process that differentiates planning, organizing, mobilizing implementation and control, by utilizing science and art, so that the stated goals are achieved (Fathurrohman.P, et.all, 2013: 149-150). In line with Usman, defines management as the process of planning, organizing, directing, and controlling organizational resources to achieve goals effectively and efficiently. Associated with education, education management is defined as the process of planning, organizing, directing, and controlling educational resources to achieve educational goals effectively, efficiently, independently and accountably. (Usman H, 2009). In other words, management is defined as the management of the effective use of resources to achieve targets (Depdiknas: $621)$.

From the above definitions, it can be understood that management is a process that continues in a direction of improvement by involving other people for the achievement of goals. Referring to the limitation of this definition, the scope of management has a wide range, and includes education management. What is meant by education management here is the activity of combining educational sources so that they are centered in the effort to achieve predetermined educational goals. So education management focuses more on managerial efforts which include planning, organizing, actuating, and controlling. Based on this description, management is an activity to achieve goals, and in achieving the objectives, actions that have been planned in advance are carried out. The prescribed actions are in the form of knowledge about what to do, determining how to do it, understanding how to do it, and measuring the effectiveness of the desired efforts. Including the need to determine and maintain an environmental condition that provides economic, socio-political response, and control (Abd Wahid Tahir, 2017).

Likewise, according to Mahmud, in the context of education, management is a process of managing and empowering all educational resources effectively and efficiently through planning, organizing, leadership, and control practices. In other words, education management is an effort to organize the field of education, especially educational institutions, so that all management functions can run effectively and efficiently so that educational goals can be achieved properly. (Mahmud, 2019: 7). Management functions in education, in general, are no different from management functions in other fields, namely including planning, organizing, directing and controlling, leadership, budgeting and financing, and evaluation (Mahmud, 2019: 95).In management, planning is the most crucial stage in all organizations, including educational organizations. Education planning is the process of formulating organizational work programs, program implementation strategies, procedures and regulations, technology tools, resources, evaluation patterns, and financing required in implementing educational programs. 
This stage is the most decisive thing that will affect the target achievement of the stated organizational goals. In the context of madrasah education institutions, planning includes planning for managerial activities as well as planning for operational activities. Organizing is a process to unite people in a work unit in order to achieve predetermined goals. In simple terms, organizing means the activity of arranging and forming working relationships between people in an organization so that a single unit is created to achieve organizational goals. The briefing is basically a process of giving directions and instructions to members of the organization so that they work according to the plan set to achieve organizational goals. The direction is the process of giving instructions, orders, directions to others. The Direction function is often referred to as the actuating function or the directing function. Actuating, namely moving and providing motivation to subordinates to perform their duties (Effendi, 2011: 20). The driving force is the entire process of providing work motivation to subordinates in such a way that they are able to work sincerely for the achievement of organizational goals efficiently and effectively (Munir, 2006: 139).

Evaluation is a planned activity to determine the state of an object by using instruments and the results are used as a benchmark for reaching conclusions. Meanwhile, the educational resources to be managed include human resources consisting of educators, educational staff, students, security personnel, to the lowest level of cleaning personnel. Meanwhile, non-human resources include infrastructure, curriculum, lesson plans, bureaucracy, and regulations. Management of madrassas is the entire process of organizing in any collaborative effort by a group of people through the use of human or non-human resources to achieve the goals of the madrasah to be effective and efficient

\subsection{Madrasah}

The term madrasah in Indonesia has been integrated with the term formal school. Many argue about the history of the emergence of madrasah in Indonesia, but it is difficult to be certain when the term madrasah is used as a type of Islamic education in Indonesia. But what is clear, madrasah have been blooming in Indonesia as Islamic education institutions since the early 20th century (Darajat, 2018)

Madrasah as Islamic educational institutions in Indonesia emerged and developed along with the entry and development of Islam in Indonesia. The madrasah has developed levels and types in line with the development of the Indonesian nation, since the sultanate, colonialism, and independence (Mulyanto et al., 2019). In its development, the education system changed from the form of recitation in houses to a mosque, mosque, and then to school buildings such as the form of madrassas known today. Likewise in terms of educational material, there were developments that previously only studied the Koran and then added practical worship lessons and continued to the recitation of the book, then religious teaching in madrasah in the form of monotheism/faith, morals, fiqh, hadith, tafsir, Islamic history. , and Arabic (Rahim, no date: 10-11

Furthermore, along with changes in government policies in the world of education, the meaning of madrasah has changed. Initially, madrasah were seen as religious education institutions, experiencing changes, especially after the ratification of the National Education System Law No. 2/1989. Madrasah are seen as uniquely Islamic public schools, or "plus schools". Changes in the definition have implications for changes in the curriculum, status, and function of madrasah in the national education system (Kosim, 2007). The National Education System Law also explains that "Madrasah" is a formal education unit that provides general and vocational education with the uniqueness of the Islamic religion, including 
Raudatul Athfal, Madrasah Ibtidaiyah, Madrasah Tsanawiyah, Madrasah Aliyah and Madrasah Aliyah Vocational.

\subsection{Previous research}

Research data relevant to this research include 'Implementation of Madrasah-Based Management in Quality Improvement' which explains that in madrasah-based management operations, several main things that need to be considered are continuous improvement, determining quality standards (Quality Assurance). Cultural change (Change of Culture) makes quality the orientation of all organizational components and organizational change. Then the research on "Implementation of Child-Friendly Learning Management in Instilling Discipline Character". The findings show that efforts to implement child-friendly learning management can have a positive impact in an effort to instill a disciplined character for students without involving elements of violence (Pamuji, 2017). Similar research on management in relation to the character found that character education in madrasah management is integrated into the process of organizing, implementing, and controlling. The implementation of management in character building is based on six management principles, namely clarity of objectives and accountability, division of tasks based on the principle of "the right man on the right place", orderly, discipline, fairness, and a spirit of togetherness (Muzayanah, 2014). Likewise, the results of Arif's research, on the management of character education planting, show that the management of madrasah institutions must be encouraged by efforts to improve the qualifications of teachers and adequate facilities and good cooperation that will encourage the improvement of the quality of Islamic education in madrasah (Arif, 2013).

Another study on management explained that madrasah are not managed professionally with systematic management which will face serious problems in the midst of global competition (Madarik, 2016). Meanwhile, Erlina, her research findings explain that the management of MIN 2 Ketenong has gone well, it can be seen from the education program that has been implemented according to plan (Erlina, 2016). Likewise, Suparman researched madrasah management, the findings were that the leadership of the head who was democratic, always prioritized deliberation with the components of the madrasah components, could create dynamic and harmonious working situations and conditions plus factors of professional human resources and adequate facilities, making the Model madrasah superior in academic achievement and non-academic, with 100\% graduation (Suparman, 2012). Meanwhile, in his findings, Nur Munajat explained that central-based management is one of the factors causing the lack of optimal improvement in the quality of Islamic education. Along with the ongoing regional autonomy (Nur Munajat, 2016). As for Jawawi, researching "Fair Management of Madrasahs" explained that there are three approaches that can be offered to overcome the weaknesses of madrasah, namely the Islamization of science, institutional legality, curriculum improvement, and improving the quality of educators (Jawawi, 2014). while the results of Buna'i's research on "Madrasah-Based Management" found that the form of MPMBM management was one way to improve the quality of madrasah, because madrasah were given the freedom to independently manage the educational process according to the wishes, needs, and demands of the community, so they could determine their own education programs ( Buna'i, 2006)

Furthermore, research on madrasah management carried out by Hikmah found that to create ideal governance, accountability, and public image of madrasahs can be done with autonomy and decentralization, school-based management and community-based management (Hikmah and Yudiawan, 2019). Meanwhile, research on the application of management principles to 
the education component at Madrasah Aliyah Ali Maksum shows less effectiveness, due to the tradition of the pesantren, the combination of the pesantren curriculum and the government curriculum, and the lack of coordination between Madrasah organizations and foundations (Roizatul Faruk, 2014).

Some of these studies discuss the same thing about management in madrasah but are more focused on managing learning and improving the quality of madrasah. While this research focuses on madrasah management in terms of planning, organizing, implementing and controlling the management of students, curriculum, personnel, facilities, finance, environment and special services. The superiority of madrasah management needs to be compared to become a rule-model that can be adopted and socialized, so that its superior values are transmitted to other madrasah. So that other madrasah can also succeed and excel and have competitiveness.

\section{RESEARCH FINDINGS AND DISCUSSION}

Based on data obtained from the field, the management of madrasah in MIN Dua, Serang Regency is quite successful. It is proven that MIN Dua has a competitive edge over other madrasah or public elementary schools which are located close to MIN Dua. These advantages are reflected in planning, organizing, implementing, and controlling in student management, curriculum, workforce, infrastructure, finance, environment, and special services.

\subsection{Student}

As explained, educational activities include managerial and operational activities. Managerial activities are activities that are more related to administrative processes, while operational activities are activities that are more related to the process of providing education (learning).

The student management in question is the whole process of activities that are planned and attempted on purpose as well as continuous guidance for all students (in the relevant educational institution) so that they can participate in the teaching and learning process effectively and efficiently starting from the admission of students to their discharge. students from a school (Ary Gunawan, 1996)

Student management includes these two main forms of activity. Managerial activities include the process of recruiting students, student recruitment quotas, student administrative data, space capacity, and distribution of student learning groups. The operational activities include academic services, counseling guidance services, student activity services, and student welfare services (scholarships).

MIN Dua Serang, in this case, has implemented fairly good management. All processes of managerial activities and operational activities in the fields of student affairs, curriculum, workforce, facilities, finance, environment, and special services begin with the planning stage through early year work meetings and periodic meetings and incidental meetings to resolve problems that arise regularly. suddenly. The meeting at the beginning of the year involved all elements of the madrasah, starting from educators, education staff, madrasah committees, and parents' representatives. All madrasah stakeholders with MIN Dua are involved in planning managerial and operational activities. This is in accordance with the planning function, namely: as a guideline for implementation and control. avoid waste of resources, tools for quality assurance development, and efforts to meet institutional accountability (Udin Syaefudin Sa'ud and Makmun, 2011). 
At this stage, for example, the capacity for the availability of classrooms is discussed, recruitment procedures (online), socialization of the recruitment process and procedures through various information facilities, and committee meetings. The new student data that has been received is then inputted by the administration through the DAPODIK system and the BUKU INDUK, then the student distribution is carried out into certain classes. In connection with this, there are various statistical data, namely available student statistics in both conventional and digital forms. Likewise, statistics for teachers and education personnel. The madrasah also periodically updates student data every semester. While the operationalization of the planning function can be seen in operational activities where the working meeting has determined the distribution of the number of groups of students, the form of formal academic services in the classroom, and enrichment of learning through tutoring in collaboration with tutors (Ganesha). Including tracing the interests of students' talents, guidance on student problems, extracurricular activities, and health services in collaboration with local community health centers (Puskesmas).

This series of activities has demonstrated an organizational function that shows the relationship between internal madrasah parties (head, educators, education personnel) and relations with external madrasah parties (comite, parents, study guidance organizations, Puskesmas) in various functions to achieve student sector targets. . Activities in the form of work meetings and committee meetings are part of the function of direction and control. In addition, internal supervision is carried out by the Head and the Regency Ministry of Religion, which embodies the function of leadership and evaluation. All of these managerial and operational activities are supported by the budgeting and financing function.

\subsection{Curriculum Management}

The curriculum is a set of subjects and educational programs provided by an educational provider that contains lesson plans that will be given to students in a period of education. In this case, the curriculum in the MI education unit has actually been designed nationally by the government, while schools or madrasah just need to implement it. However, it does not rule out the possibility for educational units to make adjustments in the form of enrichment or modification according to needs and context. This was done by MIN Dua, the curriculum was slightly modified. This is reflected in the findings of field data, where at the planning stage madrasahs form a curriculum development team that is tasked with reviewing the curriculum in accordance with the vision and mission of the madrasah. The curriculum team is in charge of determining, curriculum structure, time allocation, and determination of local content subjects. The curriculum that has been compiled by the madrasah team is then signed by the Head and then validated by the supervisor and endorsed by the Head of Madrasah Education at the Serang District Office of the Ministry of Religion. This illustrates that there is an operationalization of planning and organizing functions in the curriculum field.

To find out the implementation and progress that has been achieved by the madrasah in implementing the designed curriculum, several internal and external parties carry out monitoring activities. The internal parties involved include the Head of Madrasah Education at the Regional Office of the Ministry of Religion, the Head of Madrasah Education at the Ministry of Religion, the School and Madrasah Accreditation Board, and regularly appointed madrasah supervisors. Meanwhile, the internal parties involved include the head of madrasah and teachers. These various activities demonstrate the operationalization of the functions of direction and control, leadership, and evaluation in progress. This can be ensured that curriculum review activities, strengthening local content, monitoring and evaluation implement the operationalization of an accountable financing function. 
All contexts of these activities have referred to the quality assurance system stipulated in Permendikbud Number: 002 / H / AK / 2017 concerning the criteria and rankings for accreditation of elementary schools/madrasah ibtidayah. This is proven that MI has received an A accreditation rating. In addition, after becoming a country (1), learning tools have been developed on the competence of spiritual attitudes, social attitudes, knowledge, student skills according to the level of competence based on Permendikbud no. 37 of 2018 for general subjects and based on KMA No. 183 of 2019 for religion subject and Arabic language subject; (2) integrated thematic learning tools have been developed according to the level of competence and the scope of learning materials at each level based on Permendikbud no. 37 of 2018; (3) the principal together with the teacher develops a curriculum in accordance with the curriculum development guidelines based on Permendikbud no. 37 of 2018, KMA no. 183 years 2019, KMA no. 184 of 2019 by involving school/madrasah supervisors, resource persons, school/madrasah comite, educational institution administrators; (4) curriculum documents based on Permendikbud no. 37 of 2018, KMA No. 183 the year 2019, KMA No. 184 of 2019 which includes the vision, mission, and objectives, organizing curricular content, managing student learning loads and teacher workloads, compiling educational calendars, compiling lesson content syllabus, and compiling Chasing Implementation Plans (RPP); (5) has developed a curriculum with development operational procedures which include analysis, preparation, determination, and endorsement; (6) has implemented the curriculum in accordance with the provisions, namely: following the curriculum structure, structured assignments and independent activities, teacher workloads and student learning loads according to the provisions, arts and culture subjects and crafts are held in at least two aspects, organizing self-development activities and methods of assessment.

\subsection{Energy Management}

In the context of the workforce in the field of education, it includes both teaching staff and education personnel. The operationalization of the planning function at MIN 2 Serang is reflected in the activities of needs analysis, review of the needs of educators and education personnel, placement plans, and qualification development plans. Analysis of needs and review of needs are preparations for the recruitment of teaching staff and education personnel who will be submitted to related parties for the preparation of formations. Retention plans are related to the placement of human resources in accordance with the main duties and functions as well as competencies and qualifications. Meanwhile, the qualification development plan is an activity plan to increase the capacity and capability of madrasah human resources in various fields according to needs. Data findings from the field, MIN 2 Serang already has plans for the needs of educators and education personnel, capacity building activities, and technical qualifications such as including training in other places, workshops, training in the workplace (DDTK), technical guidance, mentoring, and assignments or placements.

The operationalization of the functions of direction and control, leadership, and evaluation is carried out through various structured patterns. The structured pattern seen from the field data includes regular ceremonies, discussions, workshops, supervision, and monitoring and evaluation, especially for the teaching staff conducted by the head of madrasah and supervisors. Other findings that are relevant to the operationalization of the management function above include: $70 \%$ of teaching staff and education personnel are able to utilize technology that supports their performance, the linearity between their education and the assignment field, the ability of teachers to compile various learning instruments, and the availability of staffing data manually and electronic. Things that still need attention from the 
government are the number of teachers out of the majority of which are still honorary status and educational staff, especially those who manage primary education data (Dapodik), are still lacking. Currently using honorary staff (Sopuan, 2020). For this reason, the Ministry of Religion as a madrasah supervisor needs to pay attention to these shortcomings. so that the management of madrasah is better which will lead to the quality output of madrasah.

This is evident from the fact that madrasahs have implemented the quality assurance system stipulated in Permendikbud Number: 002 / H /AK/2017 concerning the criteria and rankings for accreditation of elementary schools/madrasah ibtidayah. After the status change to state madrasah, it is evident that (1) the teacher has carried out a valid, objective, fair, open, holistic and accountable assessment of learning outcomes; (2) madrasahs have determined minimum completeness criteria for all subjects by considering the characteristics of students, characteristics of subjects, conditions of educational units, analysis of assessment results; (3) the teacher has carried out an assessment of learning outcomes in the form of tests, observations, assignments, and / or other forms required; (4) the teacher has used the results of the knowledge competency assessment carried out to improve the learning process, measure and determine the achievement of student competencies, compile progress reports on daily learning outcomes, mid-semester, end of semester, year-end and / or class promotion; (5) the teacher has carried out an attitude competency assessment according to the characteristics of basic competencies; (6) the teacher has carried out a knowledge competency assessment according to the characteristics of basic competencies; (7) the teacher has carried out a skills competency assessment according to the characteristics of basic competencies; (8) the teacher has carried out an attitude competency assessment through observation / observation and other relevant assessment techniques; (9) the teacher has carried out a knowledge competency assessment using written tests, oral tests, and assignments; (9) the teacher has carried out a skills competency assessment using practical tests, product assessments, project assessments, portfolio assessments, other techniques according to the competencies being assessed; (10) madrasahs have carried out assessment of learning outcomes in the form of daily assessments, end-of-semester assessments, end-of-year assessments, and school / madrasah exams; m (11) madrasah have determined student graduation by considering the results of school / madrasah exams, attitude assessments, knowledge assessments , and skills assessment; (12) the teacher has assessed the process and learning outcomes with 8 (eight) steps, namely setting assessment objectives, compiling exam grids, developing assessment instruments, analyzing instrument quality, carrying out assessments, processing and determining student graduation, reporting and utilizing rating result

\subsection{Infrastructure Management}

The infrastructure plays a very important role in supporting the effectiveness of the pursuit. Therefore, this aspect of the facility should receive the main attention by every education manager. Educational facilities generally include all facilities that are directly used and support the educational process, such as: buildings, study rooms or classes, educational equipment or media, tables, chairs, and so on. Meanwhile, what is meant by facilities / infrastructure are those that indirectly support the education process, such as: yards, gardens or school gardens, or roads leading to schools.

Basically, educational facilities can be grouped into four groups, namely land, buildings, equipment and school furniture (site, building, equipment, and furniture), so that all these facilities make a significant contribution to the course of the educational process, they should be managed properly. 
Referring to this, the minimum required educational facilities include: furniture, educational equipment, educational media, books, technology and communication facilities, experimental instruments, sports facilities, entertainment facilities, public facilities, consumables, and $\mathrm{K} 3$ facilities. The educational infrastructure includes: land, classrooms, libraries, laboratories, sports arenas, playrooms, madrasah heads, teachers' rooms, administration rooms, and public facilities such as roads, water, electricity, and data.

In this case, the operationalization of the functions of planning, direction and control, leadership, budgeting, and financing, as well as evaluation in the field of facilities and infrastructure at MIN 2 Serang is carried out regularly through the mechanism of annual work meetings. In this forum MIN 2 Serang conducts a thorough self-evaluation of madrasahs on the condition of madrasah facilities and infrastructure to analyze the needs of small things such as identifying consumables (paper and others). The working meeting forum is also a medium for identifying the needs of facilities and infrastructure, identifying the needs of the madrasah, and an inventory of madrasah facilities and infrastructure. The working meeting forum also realized the importance of educational facilities so decided to add more classrooms and plan to add land for local additions. However, until now this has not been realized. Meanwhile, the government's policy of the chasing process must be all morning. However, because local facilities are still limited, some students are still carrying out the daytime catchup process. This has hampered the ineffectiveness of improving the quality of madrasah output due to the limited time for student learning.

\subsection{Financial management}

Finance is the main factor that encourages the smooth running of the program. The function of budgeting and financing education is basically not included in the general management functional category. However, in the context of educator management, these two things are very important to support the smooth running of education. Even though MIN 2 Serang is not a satker, it still carries out its financial planning function through the mechanism of an annual work meeting involving all madrasah stakeholders as previously explained. The draft program plan and working meeting budget then become materials submitted to the Office of the Ministry of Religion. The preparation of the Madrasah Budget and Income Expenditure Plan (RAPBM) is also prepared by involving all madrasah stakeholders. Apart from that, the madrasah also prepares RKAM (Madrasah budget activity plan)), medium-term activity plans. Thus, the budget obtained comes from routine budgets, school operational assistance, and funds for incidental activities through meeting forums with parents. Budget execution is carried out by the madrasah spending treasurer who manages finances, prepares accountability reports, and documents all types of expenditure and financial expenditures. Mechanisms for guidance and control, leadership, and evaluation are carried out by internal madrasahs and external parties from the Ministry of Religion Office, the Inspectorate General of the Ministry of Religion, and the Supreme Audit Agency.

\subsection{Environmental Management}

Educational institutions in various forms, including madrasah, are basically public institutions that have a strong attachment to the environment in which they are located. In fact, it gets input in the form of students from the community and produces output in the form of graduates who will return to society. Likewise, various social aspects also shape and influence the development of curriculum and learning materials, so that educational institutions respond to all of these in the form of policies and activities, both curricular and intra-curricular activities. In this context, MIN 2 Serang has carried out communication through various 
means and opportunities with all elements of society in the school environment, especially community and religious leaders. They provide input to madrasah through certain forums, such as religious events, training for madrasa citizens, and social services. In order to develop a network of cooperation, madrasahs also collaborate with the business world (Bank Danamon) as funders for madrasah activities, the Baros Scout Branch for Camp Saturday Sunday (Advice), PT Ganesa establishes cooperation for academic improvement and other activities. (Sopuan, 2020) Likewise, various management functions operate in environmental development activities, because of the position of madrasah as organizations that are in the middle of their social and community environment. For example, the leadership function of a madrasah in establishing communication and developing cooperation with external parties. Madrasah can build harmonious interactions.

\subsection{Special Service Management}

Educational institution services are products and services provided to the community or education stakeholders: madrasah citizens, government, society, and users of graduates (world of work).In this case, it can be seen that MIN 2 Serang provides educational services to three parties, namely madrasah citizens, the government, and the community. Special services for students and educators include the provision of madrasah libraries, health services in the form of UKS and in collaboration with local health centers, security services (including road crossing services), quality control services, and cleaning services. Special services for educators and education personnel are provided in the form of various training, technical guidance, assignments, and placements in order to develop their qualifications and competencies. Meanwhile, special services to the government are in the form of providing academic and non-academic data that are regularly updated and available in both manual and digital forms. Madrasahs have also implemented various electronic applications such as Emis, Simpeg, Simak BMN, Simkeu, Vervalpd, and Verbal PDUN. Special services to the community, especially guardians of students, are provided in the form of delivering various information related to madrasah activities both conventionally and through social media. Likewise, the guidance service for tracing the interests and talents of students in its implementation in collaboration with parents in terms of financing. Previously, managerial activities at the Nurul Huda madrasah were not doing well, the administration was not neatly documented, learning was not working effectively, human resources and facilities were limited and financial administration was less accountable. This is because the leaders of private madrasah are generally held by people who are related to the owner of the foundation without paying attention to qualifications and competencies. As a result, madrasah operational activities are not running optimally.

\section{CLOSING}

\subsection{Conclusion}

From the above explanation, it can be concluded that the management of madrasah at MIN Dua in Serang Regency after the transition from private to the state has changed. Previously MIN Dua was managed by the Nurul Huda Foundation with management conditions that were not running normally both in the management of curriculum, human resources, finance, and infrastructure and others, so that madrasah activities were unstable and madrasah competitiveness decreased, until finally in 2003 Madrasah Nurul Huda can no longer operate. However, after Nurul Huda's madrasah switched to MIN Dua, it experienced 
significant changes. The management of madrasah is carried out systematically, in a structured and well-organized manner, so that the condition of the madrasah is improving. This is reflected in the increasing attractiveness of madrasah and increasingly varied pursuit activities and increasingly competent output of madrasah.

Managerial and operational activities of the madrasah, starting from student management, curriculum, personnel, facilities, finance, and others, are carried out in a planned, organized, and directed, and controlled manner. MIN Dua in planning is carried out in stages through regular and incidental meetings in solving problems, starting with evaluation, problem identification needs analysis, and planning. The implementation is carried out systematically and in an organized manner by distributing duties, powers, and responsibilities to employees, both individually and in groups, in a clear, structured, and directed manner. The implementation of these duties and responsibilities is directed and controlled by the leadership clearly and firmly in the form of technical guidance, supervision, supervision, monitoring, and evaluation. Likewise, finance is carried out, starting from the preparation of accountability reports, and documenting all types of expenditure and financial expenditure. The directive and control mechanism, namely finance is carried out by an internal party that is carried out through the madrasah SPMI (Internal Quality Assurance System). Meanwhile, external parties implemented through SPME (External Quality Assurance System) by the National Accreditation Board for Schools/Madrasahs.

\subsection{Recommendation:}

4.2.1. The Ministry of Religious Affairs needs to evaluate and supervise the operationalization of management functions for basic education units within the Ministry of Religion, so that madrasah governance is more effective and accountable so that it can encourage the improvement of the quality of madrasah.

4.2.2. The Ministry of Religion should be able to give appreciation for basic education institutions within the Ministry of Religion that can carry out their management functions properly. To provide motivation for better madrasah governance so that it becomes an accountable institution with quality output.

4.2.3. The Ministry of Religion needs to strengthen the implementation of management functions at primary level educational institutions within the Ministry of Religion so that management functions in madrasah run better in a comprehensive manner.

\section{References}

[1] Abd Wahid Tahir (2017) 'Implementasi Manajemen Berbasis Madrasah Dalam Peningkatan Mutu', Jurnal Lentera Pendidikan, 20(2).

[2] Arif, M. (2013) 'Manajemen Madrasah dalam Upaya Peningkatan Mutu Pendidikan Islam', Epistemé:Jurnal Pengembangan Ilmu Keislaman, 8(2). doi: ‘https://doi.org/10.21274/epis.2013.8.2.415438.

[3] Buna'i (2006) 'Peningkatan Mutu Madrasah (Analisis Keefektifan Manajemen Peningkatan Mutu Berbasis Madrasah)', Jurnal Tadris, 1(2).

[4] Darajat, M. (2018) 'Sejarah Madrasah Di Indonesia', Jurnal Al Afkar, 1(1).

[5] Effendi, U. (2011) Asas Manajemen. Jakarta: PT Raja Grafindo.

[6] Erlina, E. (2016) 'Manajemen Madrasah Ibtidaiyah di Kabupaten Lebong', Jurnal Manajer Pendidikan, 10(4).

[7] Fatah, N. (1996) Landasan Manajemen Pendidikan. Bandung: PT. Remaja Rosda Karya.

[8] Fathurrohman, P., Suryana, A. and Fatriany, F. (2013) Fathurrohman, P., Suryana, AA, dan [9] [9]

Fatriany, F. 2013, Jurnal Analisa. Bandung: Refika Aditama. 
[10] Hamidi (2004) Metode Penelitian Kualitatif. Malang: Universitas Muhammadiyah.

[11] Hikmah, A. N. and Yudiawan, A. (2019) 'Manajemen dan Kebijakan Madrasah melalui Penguatan

Tata Kelola, Akuntabilitas dan Citra Publik Pendidikan', ALFIKR: Jurnal Pendidikan Islam, 5(1).

[12] Jawahir Tantowi (1983) Unsur-Unsur Manajemen dalam Al-Quran. Jakarta: Pustaka Al Husna.

[13] Jawawi, A. (2014) 'Manajemen Madrasah Yang Adil', Jurnal Umul Quro, 4(2).

[14] Kosim, M. (2007) 'Madrasah di Indonesia (Pertumbuhan dan Perkembangan)', Jurnal Tadris, 5(2).

[15] Madarik, M. (2016) 'Manajmen Madrasah dalam Perspektif Islam', Cendikia: Jurnal Studi Keislaman, 2(1).

[16] Mahmud, P. (2019) Manajemen Pendidikan Tinggi. Bandung: Rosdakarya.

[17] Moleong, L. J. (2005) Metodologi Penelitian Kualitatif. Bandung: PT Remaja Rosdakarya.

[18] Morissan (2012) Metode Penelitian Survey. Kencana Prenada Media Group.

[19] Mulyanto et al. (2019) 'Modernisasi Madrasah Awal Abad Xix: Studi Analisis Madrasah

[20] Mambaul Ulum Surakarta 1905-1945', Jurnal Edukasi Islami:, 08(Jurnal Pendidikan Islam).

[21] Muzayanah, U. (2014) 'Manajemen Madrasah sebagai Media Strategis Pendidikan Karakter', Analisa, 21, p. 279. doi: 10.18784/analisa.v21i02.21.

[22] Nur Munajat (2016) 'Kebijakan Manajemen Berbasis Madrasah Dalam Meningkatkan Mutu Pendidikan Islam', Al Bidayah: Jurnal Pendidikan Dasar Islam, 8(2).

[23] Pamuji, Z. (2017) 'Implementasi Manajemen Pembelajaran Ramah Anak Dalam Menanamkan Karakter Disiplin', Jurnal Penelitian Agama.

[24] Rahim, H. (no date) Madrasah dalam Politik Pendidikan di Indonesia. Jakarta: Logos.

[25] Roizatul Faruk (2014) 'Aanalisis Fungsi Manajemen di Madrasah Aliyah (MA) Ali Maksum Krapyak Yogyakarta', Jurnal Pendidikan Agama Islam, 11(2).

[26] Sopuan (2020) Wawancara dengan Kepala MIN 2 Serang. Serang.

[27] Suparman (2012) Manajemen Berbasis Madrasah. UIN Alaudin Makasar.

[28] Suyanto and Wajah, A. (2001). (2001) Wajah dan dinamika pendidikan anak bangsa. Yogyakarta: Adi Cita.

[29] Udin Syaefudin Sa'ud and Makmun, A. S. (2011) Perencanaan Pendidikan, Suatu Pendekatan Komprehensif. Bandung: Rosdakarya.

[30] Usman H (2009) Manajemen. Teori, Praktik, dan Riset Pendidikan. Jakarta: Bumi Aksara. 